\title{
PENGARUH MODEL PEMBELAJARANINQUIRY TRAINING TERHADAP KETERAMPILAN PROSES SAINS PADA MATERI POKOK SUHU DAN KALOR KELAS SEMESTER II SMA NEGERI 1 SUNGGAL T. P.2015/2016
}

\author{
Veronicawaty Sinaga dan Juniar Hutahaean \\ Program Studi Pendidikan Fisika FMIPA Unimed \\ veronicasinarjoy@gmail.com
}

\begin{abstract}
ABSTRAK
Penelitian ini bertujuan untuk mengetahui pengaruh model pembelajaran inquiry training terhadap keterampilan proses sains siswa pada materi pokok Suhu dan Kalor Kelas X Semester II di SMA Negeri 1 Sunggal T.P 2015/2016. Penelitian ini merupakan penelitian quasi eksperimen. Populasi penelitian ini terdiri dari 6 dan pengambilan sampel dilakukan dengan cara cluster random sampling. Sampel terdiri atas kelas eksperimen dan kelas kontrol yang dipilih secara acak yaitu kelas X MIA-6 sebagai kelas eksperimen dan kelas X MIA-4 sebagai kelas kontrol yang masing-masing berjumlah 33 orang. Instrumen yang digunakan merupakan tes hasil belajar keterampilan proses sains dalam bentuk uraian dengan 9 soal yang telah divalidasi dan lembar observasi keterampilan proses sains yang dianalisis secara deskriptif dan diamati oleh lima observer. Berdasarkan hasil penelitian diperoleh nilai rata-rata pretes dan postes untuk kelas eksperimen masing-masing adalah 49,0 dan 75,3 sedangkan nilai rata-rata pretes dan postes untuk kelas kontrol masing-masing adalah 48,0 dan 67,0. Hasil observasi aktivitas belajar siswa dari pertemuan I sampai pertemuan III, mengalami peningkatan, pada pertemuan I sebesar 47,3\% (kurang baik), pertemuan sebesar II 57,4\% (cukup baik) dan pada pertemuan sebesar III 78,4\% (baik). Berdasarkan hasil uji hipotesis diperoleh bahwa ada pengaruh model pembelajaran inquiry training terhadap keterampilan proses sains siswa pada materi pokok suhu dan Kalor Kelas X Semester II SMA Negeri 1 Sunggal T.P 2015/2016.
\end{abstract}

Kata Kunci : inquiry training, keterampilan proses sains, suhu dan kalor

\begin{abstract}
This research is purposed to determine the effect of inquiry training model toscience process skills in subject Temperature and Heat in second semester $X$ grade student of SMAN 1 Sunggal in academic year 2015/2016.This research is a quasi-experimental. The population is 6 classes and sampling by cluster random sampling. The samples consist of treatment class and control class that were randomlyselectedis class X MIA-6 as an experimental class and a class X MIA-4 as a control class that each33 people. The instrument used is the achievement test science process skills in narrative form with 9 questions that have been validated and science process skills observation sheet were analyzed descriptively and observed by five observers. The research showed the average value of pretest and posttest for the experimental class was 49.0 and 75.3, while the average value for the pretest and posttest control group was 48.0 and 67.0. The observation of
\end{abstract}


learning activities of students from the first meeting to the third meeting, student learning activities for use inquiry training model increases, in the first meeting is $47.3 \%$ (less good), meeting is II $57.4 \%$ (good) and at meetings is III $78.4 \%$ (good). Based on test results obtained by the hypothesis that there is effect of inquiry training model on science process skills to students in the subject of Temperature and Heat in second semester X grade student of SMAN 1 Sunggal in academic year 2015/2016.

Keywords: inquiry training, science process skills, temperature and heat

\section{PENDAHULUAN}

Pemerintah

menyelenggarakan

perbaikan peningkatan mutu pendidikan pada berbagai jenis dan jenjang pendidikan untuk mencapai tujuan pendidikan nasional. Fakta dilapangan belum menunjukkan hasil yang memuaskan. Masalah utama dalam pembelajaran pada pendidikan formal (sekolah) dewasa ini adalah masih rendahnya daya serap peserta didik. Hal ini tampak dari rerata hasil belajar peserta didik yang senantiasa masih sangat memprihatinkan. Prestasi ini tentunya merupakan hasil kondisi pembelajaran yang masih bersifat konvensional dan tidak menyentuh ranah dimensi peserta didik itu sendiri.

Kemajuan suatu bangsa sangat ditentukan oleh kualitas sumber daya manusia dimana kualitas sumber daya manusia tersebut bergantung pada kualitas pendidikan. Pendidikan memegang peranan yang sangat penting dalam pengembangan semua potensi, kecakapan, serta karakteristik sumber daya manusia kearah positif, baik bagi dirinya maupun bagi lingkungannya.

Pelaksanaan pendidikan tidak terlepas dari proses pembelajaran di kelas. Proses pembelajaran merupakan kegiatan yang dilakukan oleh guru dan siswa secara bersama- sama untuk mencapai tujuan yang diharapkan.

Menurut Usman dalam Soeryabrata (2002:19) mengatakan bahwa proses belajar mengajar adalah suatu proses yang mengandung serangkaian perbuatan guru dan siswa atas dasar hubungan timbal balik yang berlangsung dalam situasi edukatif untuk mencapai tujuan tertentu. Inti dari pembelajaran yang diberikan oleh guru adalah agar siswa memahami konsep yang diberikan dengan baik, dengan cara yang paling mudah diterima oleh siswanya, kemudian diakhiri dengan evaluasi.

Fisika memegang peranan penting terhadap perkembangan ilmu pengetahuan dan teknologi. Fisika dalam penerapannya sangat bermanfaat dalam berbagai kehidupan, sehingga fisika perlu mendapat perhatian yang sungguhsungguh dari pihak pendidik, artinya keberhasilan dalam proses pembelajaran fisika tidak terlepas dari kegiatan-kegiatan peserta didik dan kesiapan pengajar (guru).

Banyak di antara guru yang belum dilengkapi dengan kemampuan menguasai alat praktikum sehingga siswa kurang mampu menerima umpan balik bahan pelajaran Fisika yang disajikan. Banyak guru menganggap (sadar atau tidak sadar) siswa semata-mata sebagai "objek 
belajar" bukan sebagai "subjek belajar" yang memiliki potensi intelektual dan personalitas yang perlu dimanifestasikan semaksimal mungkin mewujudkan diri menjadi manusia yaitu ketepatan seseorang di dalam menempatkan dirinya sesuai dengan kemampuan yang ada di dalam dirinya (self-actualized person) menuju ke pembentukan manusia seutuhnya (a fully functioning person).

Fisika merupakan cabang Ilmu Pengetahuan Alam yang mempelajari tentang semua peristiwa dan gejala fisis yang terjadi di alam. Pengetahuan Fisika diperoleh dan dikembangkan dengan berlandaskan pada serangkaian penelitian yang dilakukan oleh fisikawan dalam mencari jawaban pertanyaan "apa, mengapa, bagaimana" dari gejalagejala alam serta penerapannya dalam teknologi dan kehidupan sehari-hari yang melibatkan keterampilan fisis dan penalaran.Fakta yang terlihat di lapangan pada pembelajaran fisika, pembelajaran masih bersifat verbal, siswa tampak pasif dan menerima pengetahuan sesuai dengan yang diberikan guru. Proses belajar mengajar yang dilakukan di sekolah masih terpusat pada guru (teacher centered).

Sesuai dengan pengalaman peneliti saat melakukan Praktek Program Pengalaman Lapangan Terpadu (PPLT) di SMA Swasta Methodist Lubuk Pakam, banyak siswa yang menyatakan bahwa pelajaran fisika itu merupakan pelajaran yang sulit untuk dipahami dan membosankan. Mereka juga cenderung menganggap pelajaran fisika selalu identik dengan rumus yang banyak dan susah untuk diingat. Guru lebih sering mengajar dengan menyajikan materi dan penyelesaian soal-soal dengan rumus.

Metode mengajar dengan praktikum sangat jarang digunakan oleh guru karena saat itu terhambat oleh sarana dan prasarana serta pengelolaan siswa yang kurang baik. Persentasi guru menggunakan metode praktikum dalam kelas hanyalah $10 \%$. Guru di tempat penelitian yang belum pernah menggunakan model pembelajaran inquiry mengakibatkan kemampuan siswa seperti melakukan pengamatan, merumuskan hipotesis, menggunakan alat, mengumpulkan data, mengidentifikasi variabel, membuat kesimpulan dan kegiatan lain yang dapat mengembangkan keterampilan proses ilmiah yang ada pada diri siswa menjadi tidak tampak.

Kenyataan tersebut juga dijelaskan berdasarkan observasi yang telah dilakiukan di SMA Negeri 1 Sunggalbahwa nilai ulangan harian siswa masih rendah yaitu kurang dari 60 dari KKM yaitu 70. Hasil wawancara yang dilakukan oleh peneliti kepada salah seorang guru fisika SMA Negeri 1 Sunggal, beliau menyatakan bahwa hasil ulangan harian Fisika masih jauh dari yang diharapkan. Hanya beberapa orang saja yang mampu mencapai nilai di atas KKM dan selebihnya masih di bawah KKM. Observasi peneliti kepada guru di sekolah diperoleh siswa yang tertarik belajar Fisika sekitar 45, kurang menyukai Fisika 30, dan 25 ragu-ragu dari jumlah seluruh siswa kelas $\mathrm{X}$ yaitu 240 orang. Pembelajaran yang digunakan adalah pembelajaran konvensional, dan juga menggunakan model pembelajaran yang bervariasi.

Proses pembelajaran fisika masih cenderung berbasis hafalan teori, konsep-konsep dan rumus serta tidak membekali siswa pada 
keterampilan berpraktikum yang menyebabkan rendahnya keterampilan proses sains (KPS) siswa. Salah satu model pembelajaran yang dapat melatih KPS adalah model inquiry training. Tahapan model inquiry training, guru memberikan masalah kepada siswa untuk dipecahkan sendiri dimana siswa akan diberikan waktu untuk mencari jawaban melalui pengamatan, melakukan praktek sendiri atau membaca buku yang relevan. Model ini membantu menciptakan proses belajar mengajar yang akan merangsang minat dan keinginan siswa untuk mempelajari suatu hal dengan berusaha menemukan jawaban.

Hasil pembelajaran utama dari model inquiry training adalah keterampilan proses sains yang melibatkan aktivitas observasi, mengumpulkan dan mengolah data, mengidentifikasi dan mengontrol variabel, membuat dan menguji hipotesis, merumuskan penjelasan, dan menggambarkan kesimpulan.

Sintaks dari model inquiry training menawarkan pembelajaran yang aktif dan otonom. Siswa juga akan menjadi lebih terampil dalam ekspresi verbal seperti dalam mendengarkan pendapat orang lain dan mengingat apa yang telah diutarakan. Sistem sosial model pembelajaran inquiry training bersifat kooperatif dan ketat dan dapat dirancang dengan baik dimana guru mengontrol interaksi dan meresapkan prosedur-prosedur penelitian. Standar penilaian adalah kerja sama, kebebasan intelektual, dan keseimbangan. Interaksi antara siswa seharusnya juga didorong. Lingkungan intelektual terbuka untuk semua gagasan yang relevan (Joyce, dkk 2011:209)
Penelitian tentang penerapan model pembelajaran inquiry training ini telah dilakukan oleh Lumban Gaol dan Sirait (2014) yang menyatakan bahwa dengan menggunakan model pembelajaran inquiry training dapat meningkatkan hasil belajar siswa di SMA dimana untuk kelas eksperimen nilai rata-rata hasil belajarnya 71,50 sedangkan nilai rata-rata hasil belajar untuk kelas kontrol adalah 61,75. Hasil penelitian yang diperoleh memperlihatkan bahwa setelah dilakukan pembelajaran dengan model inquiry terjadi peningkatan hasil belajar siswa sebesar 9,75\%. Hasil penelitian tersebut menunjukkan bahwa model pembelajaran inquiry training dapat meningkatkan hasil belajar kemampuan proses sains siswa. Menurut Joyce dkk (2011:200) menyatakan, bahwa model pembelajaran inquiry training sebenarnya telah dikembangkan oleh Richard Suchman untuk mengajarkan siswa tentang proses dalam meneliti dan menjelaskan fenomena asing. Model Suchman ini melibatkan siswa dalam versi-versi kecil tentang jenisjenis prosedur yang digunakan oleh para sarjana untuk mengolah pengetahuan dan menghasilkan prinsip-prinsip. Didasarkan pada konsepsi metode ilmiah, model ini mencoba mengajarkan siswa beberapa keterampilan dan bahasa penelitian ilmiah.

Model pembelajaran inquiry training banyak dipengaruhi oleh aliran kognitif. Menurut aliran ini belajar pada hakikatnya adalah proses mental dan proses berpikir dengan memanfaatkan segala potensi yang dimiliki setiap individu secara optimal. Teori lain yang mendasarinya adalah teori belajar konstruktivis, teori ini dikembangkan 
oleh Piaget. Menurut piaget pengetahuan itu akan bermakna manakala dicari dan ditemukan sendiri oleh siswa. Setiap individu berusaha dan mampu mengembangkan pengetahuannya sendiri melalui skema yang ada dalam struktur kognitifnya. Skema tersebut terus-menerus diperbaharui dan diubah melalui proses asimilasi dan akomodasi. Untuk pengembangan skema tersebut adalah tugas guru untuk mengembangkannya (Sanjaya 2014:196) .

Model pembelajaran yang ditempuh para konstruktivis utamanya adalah model discovery atau inquiry dan eksplorasi. Hal ini selaras dengan pembelajaran yang dimulai dengan pengajuan masalah. Membahas perkembangan kognitif, Bruner menekankan adanya pengaruh kebudayaan terhadap tingkah laku seseorang. Belajar dan pemecahan masalah tergantung pada penyelidikan alternatif-alternatif berupa aktivasi, pemeliharaan, dan pengarahan. Teori ini menekankan tentang penemuanyang sesuai dengan tujuan peneliti

Menurut Ausabel dalam Dahar (1989:111), Struktur kognitif meliputi fakta-fakta, konsep-konsep serta generalisasi yang telah dipelajari dan diingat oleh siswa. Siswa menghubungkan atau mengkaitkan informasi baru yang diperoleh dengan pengetahuan yang telah dimilikinya, dalam hal ini terjadi belajar bermakna.Vygotsky berpendapat bahwa siswa membentuk pengetahuan sebagai hasil dari pikiran dan kegiatan siswa berupa memori, atensi, persepsi, stimulus-respondan faktor sosial fungsi mental yang lebih tinggi untuk pengembangan konsep, penalaran logis dan pengambilan keputusan" (Trianto, 2007:26-27).
Teori pembelajaran Vygotsky menekankan pada pembelajaran tingkat tinggi untuk fungsi mental yang lebih tinggi yang muncul dalam percakapan dan kerjasama antar individu dalam suatu kelompok (diskusi kelompok).

Pembelajaran inquiry training perlu mengkaitkan informasi baru pada konsep-konsep yang terdapat pada kognitif. Tokoh-tokoh aliran konstruktivisme dan kognitif di atas dapat penulis simpulkan bahwa secara umum memiliki pandangan yang sama yaitu mementingkan keterlibatan siswa secara aktif dalam belajar, baik oleh piaget yang menyatakan bahwa siswa harus menemukan dan mengembangkan pengetahuannya sendiri. Bruner menekankan adanya pengaruh kebudayaan terhadap tingkah laku seseorang untuk melakukan penyelidikan berupa aktivasi, pemeliharaan, dan pengarahan.

Ausabel menyatakan bahwa struktur kognitif meliputi fakta-fakta, konsep-konsep serta generalisasi yang dihubungkan atau dikaitkan dengan informasi baru yang diperoleh dengan pengetahuan yang telah dimilikinya, dalam hal ini terjadi belajar bermakna. Vygotsky berpendapat bahwa pengetahuan dibentuk sebagai hasil dari pikiran dan kegiatan siswa berupa memori, atensi, persepsi, stimulus-respondan faktor sosial fungsi mental yang lebih tinggi untuk pengembangan konsep, penalaran logis dan pengambilan keputusan.

Model pembelajaran inquiry training dirancang untuk membawa siswa secara langsung ke dalam proses ilmiah melalui latihan-latihan yang dapat memadatkan proses ilmiah tersebut ke dalam periode waktu yang singkat. Pengaruhnya adalah bahwa model pembelajaran inquiry training 
(latihan penelitian) akan meningkatkan pemahaman ilmu pengetahuan, produktivitas dalam berpikir kreatif, dan keterampilanketerampilan dalam memperoleh dan menganalisis informasi, latihan ini seefisien metode pengulangan dan pengajaran yang dibarengi dengan pengalaman-pengalaman

laboratorium. Hal ini dilakukan sesuai pendapat Bruner dalam Dahar (1988), bahwa selama kegiatan belajar berlangsung hendaknya siswa dibiarkan mencari atau menemukan sendiri makna sesuatu yang dipelajari. Siswa perlu diberikan kesempatan berperan memecahkan masalah seperti yang dilakukan para ilmuwan, agar mereka mampu memahami konsep-konsep dalam bahasanya sendiri.

Tujuan umum model pembelajaran inquiry training adalah membantu siswa mengembangkan disiplin intelektual dan keterampilan untuk meningkatkan pertanyaanpertanyaan dan pencarian jawaban yang terpendam dari rasa keingintahuan siswa. (Alberta,L., (2004: 14),

Model pembelajaran inquiry training memiliki lima tahap (Joyce, dkk, 2009:210) seperti ditulis pada tabel 1

Tabel 1. Tahap-tahap model inquiry training

\begin{tabular}{|c|c|}
\hline $\begin{array}{l}\text { Tahap Inquiry } \\
\text { Training }\end{array}$ & Perilaku \\
\hline $\begin{array}{l}\text { Tahap 1. } \\
\text { Menghadapkan } \\
\text { pada masalah }\end{array}$ & $\begin{array}{l}\text { - Menjelaskan } \\
\text { prosedur-prosedur } \\
\text { penelitian. } \\
\text { - Menjelaskan } \\
\text { perbedaan- } \\
\text { perbedaan. }\end{array}$ \\
\hline $\begin{array}{l}\text { Tahap } 2 . \\
\text { Mengumpulkan data } \\
\text { verifikasi }\end{array}$ & $\begin{array}{l}\text { - Memverifikasi } \\
\text { hakikat objek dan } \\
\text { kondisinya. } \\
\text { - Memverifikasi } \\
\text { peristiwa dari } \\
\text { keadaan }\end{array}$ \\
\hline
\end{tabular}

\begin{tabular}{|l|l|}
\hline \multicolumn{1}{|c|}{$\begin{array}{c}\text { Tahap Inquiry } \\
\text { Training }\end{array}$} & \multicolumn{1}{c|}{ Perilaku } \\
\hline & permasalahan. \\
\hline $\begin{array}{l}\text { Tahap 3. } \\
\text { Mengumpulkan data } \\
\text { eksperimentasi }\end{array}$ & $\begin{array}{l}\bullet \text { Memisahkan } \\
\text { variabel yang } \\
\text { relevan. } \\
\text { • Menghipotesiskan } \\
\text { (serta menguji) } \\
\text { kausal }\end{array}$ \\
\hline $\begin{array}{l}\text { Tahap 4. } \\
\text { Mengorganisasikan, } \\
\text { memformulasikan } \\
\text { suatu penjelasan. }\end{array}$ & $\begin{array}{l}\text { - Memformulasikan } \\
\text { aturan dan } \\
\text { penjelasan }\end{array}$ \\
\hline $\begin{array}{l}\text { Tahap 5. } \\
\text { Analisis proses } \\
\text { inquiry }\end{array}$ & $\begin{array}{l}\text { •Menganalisis pola } \\
\text { penelitian dan } \\
\text { mengembangkan } \\
\text { yang paling efektif }\end{array}$ \\
\hline
\end{tabular}

Sumber: (Joyce, dkk, 2009:210)

\section{METODE}

Penelitian dilaksanakan di SMA Negeri 1 Sunggal yang beralamat di jalan Sei Mencirim, Sei Semayang Kec. Sunggal. Penelitian ini dilaksanakan semester II T.P2015/2016. Populasi penelitian ini adalah seluruh siswa kelas $\mathrm{X}$ SMA Negeri 1 Sunggal T.P 2015/2016 yang terdiri dari 6 kelas dengan jumlah siswa sebanyak 240 siswa.Pengambilan sampel dilakukan secara acak kelas (cluster random sampling). Sampel yang diambil sebanyak dua kelas yang terdiri dari satu kelas eksperimen yakni kelas $\mathrm{X}$ MIA-6 dengan 33siswa yang menerapkan model pembelajaran inquiry training dan satu kelas kontrol yakni kelas X MIA-4 dengan 33siswa yang menerapkan pembelajaran konvensional.

Jenis penelitian yang digunakan dalam penelitian ini adalah jenis penelitian quasi eksperimen dengan menggunakan two group pretest and postes. Metode quasi eksperimen, yaitu penelitian yang dimaksudkan untuk mengetahui ada tidaknya akibat dari suatu yang dikenakan pada subjek yaitu siswa. Pelaksanaan penelitian, melibatkan 
perlakuan yang berbeda. Masingmasing kelas diajarkan dengan materi yang sama dengan pengajaran yang berbeda yaitu kelas eksperimen yang diajar dengan pembelajaran inquiry training (T) dan kelas kontrol yang diajar dengan pembelajaran konvensional (O). Rancangan penelitian yang digunakan adalah two group pretest and postest design seperti ditulis pada tabel dibawah ini.

Tabel 2. Two Group Pre-test and Post- test Design

\begin{tabular}{|l|c|c|c|}
\hline \multicolumn{1}{|c|}{ Kelas } & Pretes & Perlakuan & Postes \\
\hline Eksperimen & $\mathrm{X}_{1 \mathrm{E}}$ & $\mathrm{T}$ & $\mathrm{X}_{2 \mathrm{E}}$ \\
\hline Kontrol & $\mathrm{X}_{1 \mathrm{~K}}$ & $\mathrm{O}$ & $\mathrm{X}_{2 \mathrm{~K}}$ \\
\hline
\end{tabular}

Sumber: (Noor, 2011:107)

Keterangan:

$\mathrm{X}_{1 \mathrm{E}}=$ Pemberian tes awal (pretes) kelas eksperimen

$\mathrm{X}_{1 \mathrm{~K}}=$ Pemberian tes awal (pretes) kelas kontrol

$\mathrm{X}_{2 \mathrm{E}}=$ Pemberian tes akhir (postes) kelas eksperimen

$\mathrm{X}_{2 \mathrm{~K}}=$ Pemberian tes akhir (postes) kelas kontrol

$\mathrm{T}=$ Perlakuan dengan model pembelajaran inquiry training

$\mathrm{O}=$ Perlakuan dengan model pembelajaran konvensional

Tes hasil belajar yang mencakup keterampilan proses sains (KPS). Pada penelitian ini diberikan pretes dan postes pada kelas kontrol dan kelas eksperimen dengan cara siswa melakukan praktikum atau percobaan dan mengisi LKS yang disediakan untuk dapat mengamati keterampilan proses sains dari siswa. Keterampilan proses sains yang dinilai adalah keterampilan membuat hipotesis, merancang percobaan, mengumpulkan dan mengolah data, mengamati, merumuskan penjelasan dan mengidentifikasi hubungan antar variabel, dan juga keterampilan menyimpulkan.

Instrumen yang digunakan dalam penelitian ini adalah tes hasil belajar siswa yang berjumlah 9 soal dalam bentuk essay. Penelitian ini mengggunakan validitasisi.Validitas merupakan kadar ketelitian tes untuk dapat memenuhi fungsinya dalam menggambarkan aspek yang diukur dengan tepat dan teliti. Tes dikatakan valid jika tes ini dapat dengan tepat mengukur cakupan isi yang hendak diukur yang meliputi materi, kontruksi, bahasa dan penilaian umum perangkat soal.

\section{HASIL DAN PEMBAHASAN Hasil Penelitian}

Awal penelitian kedua kelas diberikan pretes (tes kemampuan awal) yang bertujuan untuk mengetahui apakah kemampuan awal siswa kedua kelas sama atau tidak. Hasil pretes pada kelas eksperimen dalam rentang nilai 0-100. Berdasarkan data hasil penelitian pretes pada kelas kontrol diperoleh nilai terendah 37 , nilai tertinggi 56 , nilai rata-rata 48 dan simpangan baku 4,6. Sedangkan di kelas eksperimen diperoleh nilai terendah 38 , nilai tertinggi 55, nilai rata-rata 49 dan simpangan baku 4,0. Hasilnya dapat ditunjukkan pada Gambar 1. 


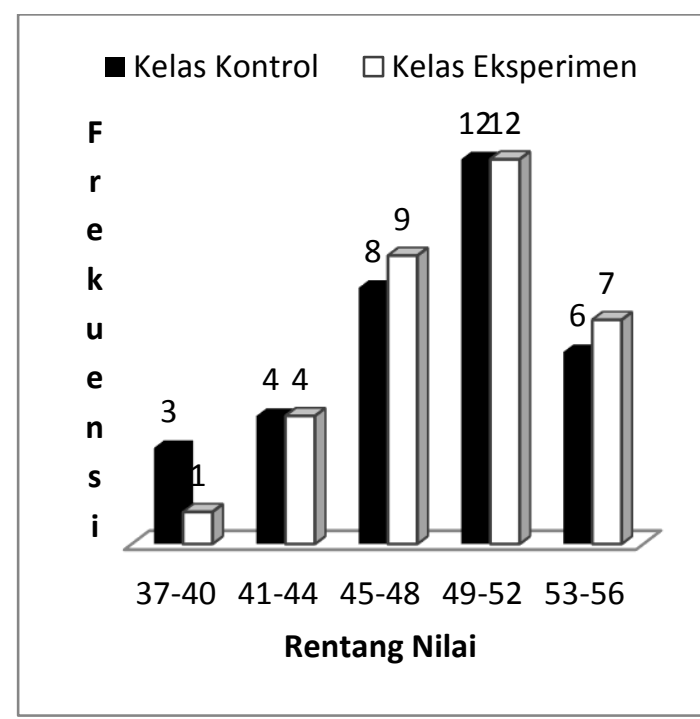

Gambar 1. Data nilai pretes kelas eksperimen dan kelas control

Data pretes memenuhi
persyaratan normalitas dan
homogenitas maka pengujian
hipotesis dalam penelitian ini
menggunakan uji kesamaan pretes
(uji t). Hasil pretes kelas kontrol dan
kelas eksperimen diperoleh nilai rata-
rata masing-masing secara berurutan
sebesar 48,0 dan 49,0. sehingga dapat
disimpulkan bahwa siswa kelas
eksperimen dengan siswa kelas
kontrol mempunyai kemampuan awal
yang sama.

Selama proses pembelajaran, pengamatan aktivitas siswa dilakukan tiga kali pertemuan setelah pretes. Aspek aktivitas yang dinilai sesuai dengan sintaks inquiry training yaitu merumuskan mengumpulkan masalah, mengumpulkan menganalisis data percobaan, dan merumuskan kesimpulan. Hasil penilaian aktivitas siswa kelas eksperimen dan kelas kontrol ditunjukkan pada Gambar 2
- Kelas Eksperimen

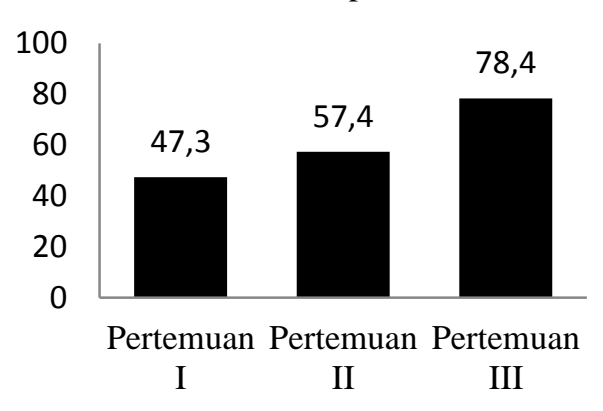

Gambar 2. Aktivitas Kelas Eksperimen

Setelah kedua kelas diberikan perlakuan yang berbeda dimana kelas eksperimen diterapkan model inquiry training sedangkan kelas kontrol diterapkan pembelajaran konvensional. Diakhir penelitian pada kedua kelas diberikan postes untuk melihat keterampilan proses sains yang di peroleh siswa. Berdasarkan data hasil penelitian postespada kelas kontrol yaitu kelas XMIA-4 yang diajarkan pembelajaran konvensional diperoleh nilai terendah 56, nilai tertinggi 74 , nilai rata-rata 67,0, dan simpangan baku 4,7. Sedangkan pada kelas eksperimenyaitu kelas X MIA6, diperoleh nilai terendah 68 dan nilai tertinggi 83 dengan nilai ratarata 75,3 dan simpangan baku 5,0. Hasil postes ditunjukkan pada Gambar 3. 
- Kelas Kontrol $\square$ Kelas Eksperimen

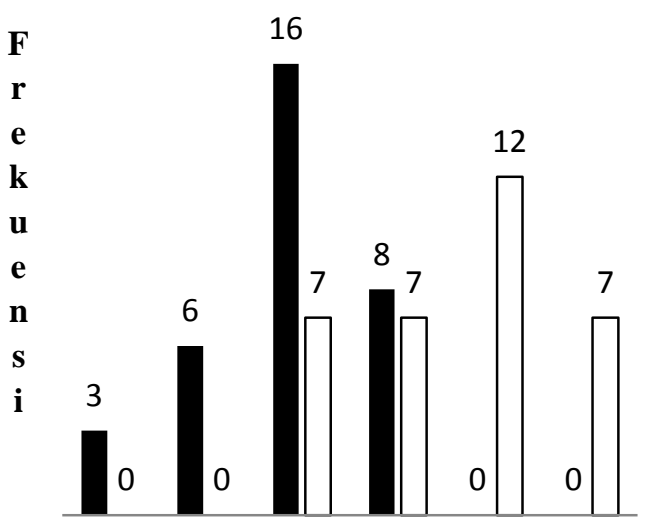

55-59 60-64 65-69 70-74 75-79 80-84

Rentang NIlai

Gambar 3. Data Nilai Postes Kelas Kontrol dan Eksperimen

Kelas eksperimen yang diajarkan dengan model inquiry training memperoleh nilai rata-rata keterampilan proses sains 75,3dan kelas kontrol yang diajarkan dengan pembelajaran konvensional memperoleh keterampilan proses sains dengan rata-rata 67,0 .

Data hasilpenelitian menunjukkan bahwa thitung $>t_{\text {tabel }}$ $(6,91>1,67)$, sehingga dapat disimpulkan bahwa keterampilan proses sains siswa lebih baik akibat pengaruh model inquiry training pada materi pokok suhu dan kalor kelas $\mathrm{X}$ Semester II SMA Negeri 1 Sunggal T.P. 2015/2016.

\section{PEMBAHASAN}

Penerapan

model

pembelajaran inquiry training ini didasarkan pada tujuannya yaitu membantu meningkatkan keterampilan proses sains siswa untuk materi Suhu dan Kalor.

Kelebihan model pembelajaran inquiry training adalah model pembelajaran ini merupakan model pembelajaran yang melibatkan seluruh siswa dalam berpraktikum dalam untuk meningkatkan kemampuan proses sains siswa terlihat dari hasil observasi siswa termaksud dalam kategori aktif.

Penelitian ini sejalan dengan hasil penelitian terdahulu yaitu Lumban Gaol dan Sirait (2012) dan Indahwati, dkk (2010) hasil belajar siswa mengalami peningkatan secara signifikan di kelas eksperimen yang menggunakan model pembelajaran inquiry training.

\section{KESIMPULAN}

Pengaruh model inquiry training lebih baik dibandingkan dengan pembelajaran konvensional terhadap keterampilan proses sains pada materi Suhu dan Kalor Kelas X Semester II SMA Negeri 1 Sunggal T.P 2015/2016.

\section{SARAN}

Sebaiknya dalam menerapkan model inquiry training agar mampu menyampaikan kepada siswa jenis pertanyaan puzzeling eventyang digunakan dalam belajar untuk memancing siswa mengutarakan pendapatnya. Dan dalam penerapan model inquiry training harus mengalokasikan waktu dengan baik agar langkah-langkahnya dapat terlaksana semuanya.

\section{DAFTAR PUSTAKA}

Alberta,L., (2004), Focus on inquiry: a teacher's guide toimplementing inquiry-based learning, Learning and Teaching Resources Branch,Canada.http://education. alberta.ca/media/313361/focuso ninquiry.pdf(Diakses Desember 2012) 
Dahar, R. W., (1988), Teori-teori Belajar, Erlangga, Jakarta

Indahwati, T. S. J., Sunarno,w., Sajidan.,(2010),Penerapan Model Inquiry Training Melalui Teknik PetaKonsep dan Teknik Puzzle Ditinjau Dari Tingkat Keberagaman Aktivitas Belajar dan Kemampuan Memori Jurnal InkiuriISSN: 2252-7893, Vol 1, No 3, 2012 (hal 258265)

Lumban Gaol, D .K., Sirait, M., (2014) Pengaruh Model Pembelajaran Inquiry TrainingMenggunakan Media Powerpoint TerhadapHasil Belajar Siswa, Jurnal Inpafi, Vol. 2, No. 2, Mei 201430

Joyce, B.,Wheil, M., Calhoun, Emily., (1996), Models of Teaching, Fifth Edition, Prentice-Hall, Inc., Englewood Cliffs, New Jersey.

Joyce, B., Wheil, M., Calhoun, Emily., (2009),Model-model Pembelajaran, Edisi Delapan, Pustaka Pelajar, Yogyakarta

Noor, J., (2011),Metodologi Penelitian, Kencana, Jakarta

Sanjaya, W., (2010),Strategi Pembelajaran, Kencana, Jakarta

Soeryabrata, (2002), Psikologi Pendidikan, Raja Grafindo, Yogyakarta

Sudjana, (2005),Metode

Statistika,Tarsito, Bandung
Trianto,(2007),Mendesain Model Pembelajaran InovatifProgresif, Kencana, Jakarta 